INVESTIGATIONES LINGUISTICAE VOL. XXXIX, 2018

(C) INSTITUTE OF LINGUISTICS - ADAM MICKIEWICZ UNIVERSITY

AL. NIEPODLEGŁOŚCI 4, 60-874, POZNAŃ - POLAND

\title{
Tłumacze bez Granic a status thmacza
}

\author{
Patrycja Masłowska \\ INSTYTUT FILOLOGII ROMAŃSKIEJ, UNIWERSYTET IM. ADAMA MICKIEWICZA \\ AL. NIEPODLEGEOŚCI 4, 61-874 POZNAŃ \\ pm80677@amu .edu.pl
}

\begin{abstract}
The objective of the present article is to analyse the influence of the organisation Translators Without Borders on the status of its volunteers: translators and community interpreters. The first chapter concerns main aspects of the translator's status. The second one presents briefly the types of Translators Without Borders activities, while the next one focuses on the characteristics of the types of translator's and interpreter's work for the organization. The last chapter includes the analysis of the translator's and interpreter's status aspects that are susceptible to impact of the described organization's activities. Conclusions are ambiguous as the main reason of the Translators Without Borders foundation was not to improve the translator's status. However, membership may be beneficial under certain conditions.
\end{abstract}

\section{Status tłumacza}

Status tłumacza to wszystkie aspekty związane $\mathrm{z}$ osobą tłumacza, $\mathrm{z}$ warunkami jego pracy i jego własnym ich postrzeganiem. W praktycznym podejściu do statusu tłumacza Douglas Robinson posuwa się nawet do stwierdzenia, że tłumaczenie jest bardziej związane z ludźmi niż z samymi słowami (Robinson, 2003: 35). W związku z tym tak istotne jest, żeby tłumacz czuł się komfortowo w warunkach, w jakich wykonuje swoją pracę. Istnieją wtedy większe szanse na satysfakcję, chęć doskonalenia się, a wreszcie - wysoką jakość wykonywanych tłumaczeń, niemożliwą do osiągnięcia jeśli ktoś nie jest przekonany do tłumaczenia bądź musi je wykonywać w złych warunkach. Wówczas dążenie do podnoszenia jakości tłumaczenia będzie nieskuteczne lub tłumacz zniechęci się do przymusowej pracy, a przez to stanie się niewiarygodny. $\mathrm{Z}$ punktu widzenia statusu tłumacza, ważne jest poczucie, że jego praca jest ważna, dobrze wykonywana oraz że jest potrzebna i doceniana przez innych. Dużą rolę odgrywa też poczucie wspólnoty, realizowane poprzez udział w konferencjach, warsztatach podnoszących kwalifikacje, przynależność do stowarzyszeń tłumaczeniowych, możliwość wymiany myśli na temat warunków wykonywania tłumaczenia i jego jakości. Także użycie nowych technologii wspomagających tłumaczenie dobrze wpływa na warunki pracy poprzez jej ułatwienie i skrócenie czasu potrzebnego do jej wykonania

(Robinson, 2003: 24-34). 
Choć czynność tłumaczenia sama w sobie może dawać wiele zadowolenia i tłumaczy nie brakuje, w stosunku do stopnia i licznych jej trudności, konieczności zaangażowania i poświęcenia długich nieraz godzin na przełożenie tekstu, wynagrodzenie i społeczny odbiór postaci tłumacza wciąż są niewystarczające (Robinson, 2006: 33). Szerzej o tym pisał Venuti (Venuti, 1995, 1998) w kontekście przekładu pisemnego, oraz Tryuk (Tryuk, 2006: 10, 20-21) pod kątem przekładu środowiskowego. Kładę nacisk na te dwa rodzaje tłumaczenia, gdyż są to dwa najczęściej przez Ttumaczy Bez Granic stosowane rodzaje tłumaczenia, o czym będzie mowa niżej.

Jako że celem niniejszego artykułu jest rozważenie, na ile powyższe aspekty statusu tłumacza są realizowane przez organizację Thumacze bez Granic, w pierwszej kolejności konieczne będzie scharakteryzowanie jej działalności, a następnie opisanie, jakiego rodzaju tłumaczenia wykonują jej wolontariusze. W ostatniej części artykułu omówię, na ile działalność Ttumaczy Bez Granic realizuje pozytywne strony statusu tłumacza.

\section{Thumacze bez Granic}

Ttumacze bez Granic to organizacja non-profit, która powstała na wzór Lekarzy bez Granic, z którymi współpracuje, oferując nieodpłatne usługi językowe, przede wszystkim tłumaczeniowe, w zakresie takich obszarów jak na przykład zdrowie, żywienie, edukacja. Głównym celem organizacji jest pomoc osobom poszkodowanym na skutek kryzysów humanitarnych, epidemii, wojen czy katastrof naturalnych (Thicke, 2002). Jej członkowie wierzą, że w takich sytuacjach tłumaczenie może uratować zdrowie, a nawet życie, poprzez wymianę ważnych informacji $\mathrm{w}$ zrozumiałym dla poszkodowanych języku. Ponieważ wyżej wymienione kryzysy następują często w miejscach, gdzie znajomość angielskiego nie jest powszechna, organizacja specjalizuje się $w$ językach rzadkich, o małej liczbie użytkowników i o małym zasięgu geograficznym. Oprócz Lekarzy Bez Granic, współpracują z innymi organizacjami, o podobnych celach, jak Reporterzy Bez Granic, Amnesty International, Handicap International“ (Baker, 2006: 477), Rosetta Foundation (Anastasiou, Schäler, 2010: 23).

Działalność Ttumaczy Bez Granic jest wbrew pozorom bardzo szeroka i skupia się na kilku filarach (informacje na temat działalności pochodzą ze stony: https://translatorswithoutborders.org, zakładka „Our work"): oprócz flagowej pomocy przy kryzysach humanitarnych w zakresie tłumaczenia pisemnego i ustnego, organizują szkolenia tłumaczy w zakresie lokalnym (głównie języki o małej liczbie użytkowników) oraz dążą do podnoszenia świadomości o barierach językowych i wadze tłumaczenia na skalę światową, współpracują z innymi organizacjami nad zbieraniem i popularyzowaniem danych o językach z obszarów dotkniętych klęskami, a także dążą do upowszechniania i usprawniania narzędzi tłumaczeniowych, przede wszystkim tłumaczenia maszynowego i innych narzędzi technologicznych, czego przykładem może być współpraca przy tworzeniu aplikacji na smartfony do postedycji tłumaczenia (O'Brien, Moorkens, Vreeke: 2016). 
Jakie jest miejsce tłumaczy $\mathrm{w}$ tych działaniach? Spróbujmy się przyjrzeć konkretnym projektom $\mathrm{z}$ uwzględnieniem obowiązków wykonywanych przez wolontariuszy. Podczas wieloletniego istnienia Ttumacze bez Granic wykształcili pewne mechanizmy działania. Jednym z nich jest Words of Relief, który ma na celu umożliwienie komunikacji między poszkodowanymi a ratownikami na miejscu zdarzenia. $\mathrm{W}$ jego ramach tłumacze przygotowują zestaw najpotrzebniejszych sformułowań, które umożliwią prawidłową komunikację, i co za tym idzie, właściwy sposób pomocy potrzebującym. Są to czasem bardzo podstawowe wyrażenia, dotyczące ogólnych zasad zachowania albo pytania o samopoczucie, ale też bardziej wyspecjalizowane terminy dotyczące chorób czy dolegliwości. Udostępnia się je między innymi poprzez darmowe, powszechnie dostępne aplikacje. Oprócz tego organizacja ma stały kontakt $\mathrm{z}$ siecią tłumaczy, którzy $\mathrm{w}$ razie potrzeby, na wezwanie organizacji, przybędą na miejsce i udzielą pomocy. Ten model pomocy, dostosowywany zawsze do potrzeb aktualnej sytuacji, jest stosowany od 2014 roku. Używano go wielokrotnie: w Afryce Zachodniej przy epidemii eboli, kiedy to w jego ramach powstał m.in. glosariusz $\mathrm{z}$ ponad stoma elementami $\mathrm{w}$ ponad trzydziestu językach; w 2015 r. w Nepalu po trzęsieniu ziemi; w 2016 r. na Haiti, kiedy opracowano tłumaczenie do filmu o zapobieganiu wirusowi zika; w tym samym roku i też na Haiti, kiedy po huraganie Matthew wykonano tłumaczenia treści geograficznych i materiałów z informacjami o zapobieganiu cholery.

Innym aspektem działalności jest zapobieganie ewentualnym nieszczęściom. Chodzi tu o to, aby rozpowszechniać ważne informacje $\mathrm{w}$ odpowiednich językach. Na przykład, projekt Simple Words for Health polega na tym, aby wykwalifikowani lekarze i wyspecjalizowani tłumacze medyczni tłumaczyli terminologię medyczną, która pozwoli w razie potrzeby na sprawną komunikację. Dotąd opracowano ponad 12 ooo terminów w ponad czterdziestu językach. Podobny projekt, Wiki 10ox1oo, ma na celu przetłumaczenie 80 najważniejszych artykułów medycznych na przynajmniej 80 języków docelowych, co pomoże w rozpowszechnianiu podstawowej wiedzy o zdrowiu.

Ważnym aspektem działalności jest też Kató, platforma umożliwiająca kontakt między tłumaczami wolontariuszami a organizacjami potrzebującymi nieodpłatnych usług tłumaczeniowych. Daje ona możliwość uzyskania tłumaczeń w ponad 250 parach językowych. Thumacze bez Granic pośredniczy w tym kontakcie, oferując tłumaczom zaawansowane narzędzia wspomagania maszynowego, ułatwiające i usprawniające wszystkie rodzaje tłumaczenia, w tym też tłumaczenie napisów filmowych i podkładanie głosu do filmów.

\section{Tłumaczenie pisemne specjalistyczne i ustne środowiskowe}

$\mathrm{Z}$ powyższego wynika, że $\mathrm{w}$ projektach potrzebne jest wykonywanie tłumaczeń pisemnych (w tym specjalistycznych, głównie $\mathrm{w}$ zakresie medycyny), jak i ustnych, przede wszystkim środowiskowych. Czym się one 
charakteryzują? Wykonywane przez tłumaczy specjalistycznych tłumaczenie „polega na przekazywaniu komunikatu (message), który ma określoną treść, formę dyskursu i terminologię, i który ma określony, zwykle doraźny cel“ (Berman, 1991). Co więcej, od tłumaczy specjalistycznych wymaga się tłumaczenia tekstów w taki sposób, aby przekazywały informacje „w sposób jasny, odpowiedzialny i skuteczny“, a tekst docelowy dostosował się do typu swoich odbiorców tak, jak tekst wyjściowy był napisany pod kątem typu swoich odbiorców, oraz aby był „dostosowany do sytuacji pragmatycznej w kulturze języka docelowego“ (Berman, 1991). W kontekście Ttumaczy Bez Granic warto podkreślić doraźny i pragmatyczny charakter tłumaczenia: podlega mu na przykład terminologia potrzebna do projektu Simple Words for Health, albo teksty z zakresu medycyny do projektu Wiki 1Oox1oo, które w określonej sytuacji, miejscu i czasie mają za zadanie dostarczyć informacji np. o zapobieganiu chorobom lub o poprawnym zaopatrywaniu rannych. Aby spełniły swoją funkcję, muszą być jasne i zrozumiałe, dostosowane do swoich odbiorców, bo to od tego, czy ci odbiorcy (którymi są członkowie mniejszościowych grup językowych chcący uzupełnić wiedzę o zdrowiu lub metodach leczenia, a także ci członkowie i wolontariusze humanitarni w czasie akcji ratowniczych) zrozumieją komunikat, będzie zależało, czy będą mogli się do niego zastosować. Stąd duża odpowiedzialność spoczywająca na tłumaczach specjalistycznych. Na szczęście, współcześnie mają oni do dyspozycji coraz liczniejsze narzędzia do tłumaczenia maszynowego lub do tłumaczenia wspomaganego komputerowo, które usprawniają i ułatwiają pracę, dzięki czemu rola samego tłumacza ogranicza się do sprawdzenia i poprawienia gotowego tłumaczenia przetłumaczonego maszynowo (Dąmbska-Prokop, 2000: 256). Jako że, jak wspomniano wyżej, rozwój pomocy technologicznych jest jednym z aspektów działalności Ttumaczy Bez Granic, część tłumaczy specjalistycznych bierze udział w opracowywaniu takich narzędzi, glosariuszy, baz terminologicznych i aplikacji.

$\mathrm{Z}$ kolei tłumaczenie środowiskowe jest definiowane jako podtyp tłumaczenia ustnego, które odbywa się w sferze publicznej pomiędzy zwykłymi ludźmi a przedstawicielami władz (Wadensjö, 2001: 33), choć w przypadku Ttumaczy Bez Granic do tej kategorii należeć będą także między innymi lekarze, pielęgniarze $\mathrm{i}$ ratownicy $\mathrm{z}$ partnerskich organizacji. Tłumacze środowiskowi tłumaczą zarówno ich wypowiedzi, jak i wypowiedzi drugiej strony w czasie rzeczywistym. To prawdopodobnie najczęściej wykonywane tłumaczenie ustne na świecie, a podejmują się go nawet osoby niewykwalifikowane. Powodem tego jest częściowo dotychczasowy brak szkoleń w tym zakresie, co od kilku dekad zaczyna się zmieniać. Bardzo charakterystyczny dla tłumaczy środowiskowych jest problem zachowania neutralności wobec obu stron, tak ważny dla przebiegu komunikacji, a w praktyce trudny do osiągnięcia. Zwłaszcza że tłumacze często muszą, oprócz bycia pośrednikami w przepływie komunikatów między obiema stronami, aktywnie angażować się w dialog między nimi (Wadensjö, 2001: 33-34). Dwie komunikujące się strony zazwyczaj mają odmienny status społeczny i różny zakres kompetencji i wiedzy. Tłumacz, uczestnicząc w żywej 
rozmowie, sam mimowolnie staje się jej uczestnikiem i zazwyczaj musi zająć w niej jakąś pozycję. Sama rola tłumacza jest płynna i trudno rozgraniczyć, co jeszcze należy do kompetencji tłumaczeniowych, a co już nie. Na przykład, tłumacz może domyślać się intencji jednej z osób i przekazywać je werbalnie, jako dodatkowy komunikat, jeśli podejrzewa, że druga osoba mogłaby się tych intencji nie domyślić, a jest to istotne z punktu widzenia zachodzącej między nimi komunikacji. Częstym dylematem jest zajęcie pozycji po którejś $\mathrm{z}$ dwóch stron: tłumacz może stać się "obrońcą" poszkodowanego i starać się tak przedstawić jego komunikaty w taki sposób, aby przekonać władze do jego racji, lub przeciwnie, być „narzędziem w rękach władzy“, co może negatywnie odbic się na jakości komunikacji - któraś ze stron może być zniechęcona tym, że ma do czynienia z wrogo sobie nastawionymi osobami (Tryuk, 2006: 27-29). Tryuk zauważa też, że obecnie „W wielu krajach zachodnich środowisko tłumaczy domaga się, aby przekład środowiskowy stał się częścią publicznych służb socjalnych (...).“ a także, co bardzo ważne - „(...) tłumacz środowiskowy powinien nie tylko ułatwiać komunikację między rozmówcami, ale i odgrywać pierwszoplanową rolę $\mathrm{w}$ procesie integracji, $\mathrm{w}$ walce $\mathrm{z}$ uprzedzeniami i dyskryminacją." (Tryuk, 2006: 31). Zwłaszcza ten ostatni aspekt pracy tłumacza środowiskowego idealnie zbiega się z celami Ttumaczy Bez Granic, którzy ten postulat realnie spełniają poprzez umożliwienie komunikacji tym, którzy nie posługują się najczęściej używanymi na świecie językami, w krytycznych dla nich momentach, kiedy ta komunikacja może zadecydować o np. ich zdrowiu lub bezpieczeństwie.

\section{Wpływ Thumaczy Bez Granic na status thumacza}

Wiemy już, na czym polega działalność Tłumaczy Bez Granic, a także jaki jest status i czym się charakteryzuje praca tłumaczy pisemnych oraz środowiskowych, pracujących na rzecz organizacji. Prowadzi to do pytania, jak te dwa aspekty mają się do siebie? Czy założenia i działalność Ttumaczy Bez Granic podnosi, czy obniża status tłumaczy, i w jakim stopniu?

Odpowiedź na to pytanie nie będzie jednoznaczna. Przede wszystkim, należy mieć na względzie, że Ttumacze bez Granic nie jest organizacją skupiającą się na potrzebach tłumaczy - z założenia, jej priorytetem jest różnoraka pomoc ofiarom kryzysów humanitarnych, a tłumacze mają za zadanie nieść tę pomoc. Jest to działalność mająca szczytny cel, wzorowana na działalności innych organizacji „bez granic“ (Lekarze Bez Granic, Reporterzy Bez Granic), tzn. organizacji, którym przyświeca idea społecznej sprawiedliwości, pozarządowych, ponad politycznymi podziałami, skupionych wyłącznie na potrzebach poszkodowanych ludzi, bez względu na ich tożsamość (Fox, 1995: 1607). Sama przynależność i zaangażowanie w tego typu działalność pozytywnie wpływa na odbiór tłumaczy jako osób pełniących szlachetną misję humanitarną (Anastasiou, Schäler, 2010: 24; Désilets, 2011: 32), co pozwala im przypisać ważną rolę społeczną i kulturową. Poza tym, usługi tłumaczeniowe odznaczają się prestiżem, tak jak usługi prawnicze, gdyż tylko wąskie grono odbiorców ma do nich dostęp (Thicke, 2002). Aby te i inne informacje dotarły do jak najszerszego grona 
czytelników, Tłumacze bez Granic promują swoją działalność na różne sposoby, głównie poprzez stronę internetową (https://translatorswithoutborders.org), gdzie znaleźć można aktualizowane regularnie informacje i statystyki o podjętych inicjatywach. Na stronie znajdują się też teksty i nagrania (np. w ramach wystąpień TEDx) o wadze usług językowych (w tym tłumaczenia) w sytuacjach kryzysowych, czym również, między innymi, Ttumacze bez Granic starają się podnieść wagę swoich działań. Ten aspekt działalności realizują nie tylko poprzez stronę internetową, ale i przez media, prasę, kontakt z partnerami. Istnienie organizacji i promowanie jej działalności zwiększa jej widzialność, a pośrednio także osób samych tłumaczy.

Organizacja docenia swoich członków też w bardziej bezpośredni sposób - poprzez promocję swoich najaktywniejszych tłumaczy. Na stronie internetowej, w specjalnie im poświęconej zakładce, „Our volunteers“, zamieszczone są ich profile zawierające imię i nazwisko, języki, w obrębie których pracują, ich zdjęcie, inicjatywę, w jaką są zaangażowani oraz dodatkowo czas lub liczbę słów tłumaczenia na rzecz organizacji i odnośnik do wywiadu, jeśli takowy został $\mathrm{z}$ danym tłumaczem/daną tłumaczką przeprowadzony. Informacje o członkach można znaleźć też w zakładce „Our team“. W ten sposób tożsamość tłumaczy spełniających ważne założenia organizacji, ale wcześniej anonimowych zostaje odkryta, co pokazuje, że organizacja to nie tylko abstrakcyjne wartości, ale i konkretni ludzie, którzy pracują nad ich spełnianiem. To również podkreśla podmiotowość tłumaczy - nie jest tylko tak, że organizacja zrzesza osoby odpowiadające jej profilowi działalności, ale też każda z zaangażowanych osób wnosi swoje indywidualne zaangażowanie. Skutek jest ten sam pokazanie organizacji w dobrym świetle - ale pokazany od innej strony, strony podkreślającej wkład poszczególnych osób, co nie jest bez wpływu na sposób ich postrzegania.

Wątpliwości co do charakteru działań Tłumaczy Bez Granic może budzić brak informacji odnośnie do sposobu weryfikacji jakości ich usług. Jest to istotne $\mathrm{z}$ punktu widzenia zaufania, $\mathrm{z}$ jakim można powierzyć tłumaczenie organizacji, bo osoby potrzebujące tłumaczenia na ogół nie są w stanie ocenić, czy jest ono wykonane dobrze czy źle. Jeśli zwracamy się o tłumaczenie do konkretnej osoby, to jej postawa i podejście do swojej roli świadczą o wiarygodności - tutaj tę funkcję przejmuje sama organizacja, reprezentująca swoich tłumaczy i określająca jakość oraz warunki ich pracy. Na stronie internetowej Ttumaczy Bez Granic łatwo można odnaleźć cele czy sposoby realizacji ich działalności, prośbę do przyłączenia się jako wolontariusz lub partner, a także zachętę do wsparcia finansowego. Opisy działalności i zaangażowanych $\mathrm{w}$ nią członków skupiają się na ich profesjonalizmie opartym głównie na doświadczeniu: latach pracy i rodzajach projektów, w których uczestniczyły poszczególne osoby. Jednak ani w żadnej ze stałych zakładek, ani w raporcie rocznym nie ma nic na temat ich wykształcenia, odbytych studiów, szkoleń. W formularzu zgłoszeniowym kandydaci na tłumaczy „bez granic“ są proszeni o wskazanie lat doświadczenia oraz kwalifikacji, nie wiadomo jednak, na ile jest to 
kryterium przyjęcia. Jednym z założeń Tłumaczy Bez Granic jest fakt, że informacja nieprzetłumaczona na zrozumiały dla danej społeczności język lub przetłumaczona niewłaściwie może decydować o życiu lub zdrowiu, więc należy wierzyć, że organizacja dokłada wszelkich starań, aby poprzez usługi językowe poprawiać sytuację $\mathrm{w}$ miejscach kryzysu. O profesjonalizmie tłumaczy-wolontariuszy zapewnia też sama prezes (Thicke, 2002). Jednakże, żaden podmiot zewnętrzny nie ocenia ani nie kontroluje przebiegu czy efektu tłumaczenia.

$\mathrm{Na}$ inny aspekt, tym razem ideologiczny, zwraca uwagę Mona Baker. Chodzi o to, że organizacja Ttumacze bez Granic powstała jako projekt typu non-profit związany z innym projektem, komercyjnym, Eurotexte (oba założone przez Lori Thicke) i to bliskie, wciąż podtrzymywane powiązanie wpływa na niespójność założeń organizacji. Tłumacze bez Granic widnieją na stronie internetowej (https://www.lexcelera.com/ ) jako partnerzy Lexcelery (na taką nazwę przemianowano w 2006 Eurotexte) obok partnerów komercyjnych, z kolei tłumacze Lexcelery po godzinach pracują na rzecz organizacji non-profit. Najpoważniejszy zarzut dotyczy jednak współpracy Lexcelery z przedsiębiorstwami o wątpliwej reputacji moralnej, które wyrządziły szkody humanitarne, którym $\mathrm{z}$ kolei stara się przeciwdziałać „siostra“ Lexcelery, Ttumacze bez Granic. Tym samym, dwie organizacje współpracują z tymi przedsiębiorstwami (chodzi m.in o L'Oréal, które na swoją siedzibę na Bliskim Wschodzie wybrało Izrael, co wpłynęło na znaczny rozwój izraelskiej gospodarki, i które jest przez to bojkotowane przez wiele organizacji), a jednocześnie potwierdzają ich szkodliwość, pomagając ich ofiarom. To zaburza ich spójność ideologiczną, a tym samym podważa wiarygodność ich pozytywnych intencji (Baker, 2006: 477-480).

$\mathrm{Na}$ koniec należy podkreślić nieodpłatny charakter członkostwa w Tłumaczach Bez Granic - choć jest to oczywiste założenie, na którym opiera się istnienie organizacji i które świadczy o bezinteresowności pozytywnych intencji wolontariuszy, nie polepsza ono statusu ekonomicznego tłumaczy. Niektóre z wymienionych projektów, jak Simple Words for Health i Wiki $100 x 100$ są finansowane przez sponsorów, co można przeczytać na stronie internetowej organizacji (https://translatorswithoutborders.org/ourwork/development/), jednak informacje o finansowaniu nie są uporządkowane ani klarowne. Na przykład, kto opłaca szkolenia tłumaczy ustnych? Albo tłumaczy z projektu Words of Relief? Na jakich zasadach odbywa się finansowanie? W raporcie na rok 2017, dostępnym na stronie internetowej, podane są dokładne sumy i źródła finansowania działalności, ale nie wiadomo, jaka część z tego i na jakich zasadach przypadła w udziale tłumaczom. Nie ulega wątpliwości, że nawet jeśli znajduje się sponsor gotowy pokryć koszty określonych aspektów działalności organizacji, jest to raczej wynagrodzenie jednorazowe, a stawki nie są podawane do ogólnej wiadomości, co utrudnia ich ocenę. Choć postulaty o zmianę statusu tłumaczy, zwiększenie ich widzialności i podwyższenie wynagrodzenia dotyczą wszystkich rodzajów tłumaczy, ten negatywny aspekt uderza zwłaszcza w tłumaczy środowiskowych, których status jest szczególnie niedoceniany. 
Podsumowując, należy zapytać, na ile z satysfakcji tłumacza, opisanej przez Douglasa (patrz „Status Tłumacza“), mogą liczyć wolontariusze Ttumaczy Bez Granic? Największym negatywnym aspektem pracy na rzecz organizacji jest jej nieodpłatny charakter. Również sama praca jest wymagająca - odbywa się ona często w warunkach kryzysowych, pod presją czasu i odpowiedzialności za czyjeś bezpieczeństwo, zdrowie lub życie. W zamian za jej świadczenie tłumacze muszą zadowolić się poczuciem, że uczestniczą w wartościowym przedsięwzięciu. Nie bez znaczenia jest też fakt przynależności do wspólnoty, w której tłumacze mogą wspólnie i ze wzajemnym wsparciem osiągać cele i doskonalić swoje umiejętności. Mimo że powodem powstania Ttumaczy Bez Granic nie jest walka o poprawę warunków tłumaczenia, wolontariusze mogą korzystać z najnowszych technologii wspomagających tłumaczenie, gdyż pomagają one podnosić jakość wykonywania i efektu tłumaczenia, o co zabiega organizacja. Samo istnienie Ttumaczy Bez Granic zwiększa też widzialność tłumaczy w przestrzeni publicznej i podnosi rangę ich statusu poprzez wpisanie ich $\mathrm{w}$ schemat organizacji „bez granic“, tzn. zwalczających dyskryminację i zabiegających o lepsze warunki życia dla osób ze społeczności mniejszościowych. Przynależność do takiej organizacji, jeśli posiada się źródło zatrudnienia i ochotę do wykonywania tłumaczenia, może być wartościowym doświadczeniem zawodowym i społecznym. 
Patrycja Masłowska: Ttumacze bez Granic a status thumacza

\section{Bibliografia}

Anastasiou, D., Schäler R. 2010. Translating Vital Information: Localisation, Internationalisation, and Globalisation, w: Dimitroulia X. (ed.) Syn-Thèses, pp.11-25.

Baker, M. 2006. Translation and Activism: Emerging Patterns of Narrative Community, w: The Massachusetts Review, Vol. 47, No. 3 (Fall, 2006), pp. 462-484.

Berman, A. (1991). Traduction specialisée et traduction littéraire w: $L a$ traduction littéraire, scientifique et technique, Actes du colloque international organisé par l'Association Européenne des Linguistes et des Professeurs de Langues (AELPL), Paryż, w: Dąmbska-Prokop U. Ttumaczenie specjalistyczne, pp. 255-256, w: Dąmbska-Prokop U. (ed.) 2000. Mała Encyklopedia Przekładoznawstwa. Częstochowa: Wydawnictwo Wyższej Szkoły Języków Obcych i Ekonomii.

O'Brien, S., Moorkens, J., Vreeke J. 2016. Kanjingo - A Mobile App for Post-Editing, w: Revista Tradumàtica 14 (14), pp. 58-66.

Dąmbska-Prokop, U. (ed.) 200o. Mata Encyklopedia Przektadoznawstwa. Częstochowa: Wydawnictwo Wyższej Szkoły Języków Obcych i Ekonomii.

Désilets, A., Meer, van der J. 2011. Co-creating a repository of best-practices for collaborative translation, w: O'Hagan M (ed.) Linguistica Antverpiensia, New Series - Themes in Translation Studies, pp. 27-45.

Fox, R. C. 1995. Medical Humanitarianism and Human Rights: Reflections on Doctors Without Borders and Doctors of the World, $w$ : Social Science \& Medicine, Volume 41, Issue 12, December. 1995, pp. 1607-1616, cytowane w: Baker M. 2006. Translation and Activism: Emerging Patterns of Narrative Community w: The Massachusetts Review, Vol. 47, No. 3 (Fall, 2006), p. 477.

Oficjalna stona internetowa Lexcelera https://www.lexcelera.com/

Oficjalna stona internetowa Translators Without Borders https://translatorswithoutborders.org/

Robinson, D. 2003 Becoming a Translator. An Introduction to the Theory and Practice of Translation. Londyn i Nowy Jork: Routledge.

Thicke, L. 2002. The Humanitarian Face of Translation, w: Multilingual, Vol. 13, Issue 4, 34-36.

Tryuk, M. 2006. Przekład ustny środowiskowy. Warszawa: Wydawnictwo Naukowe PWN.

Venuti, L. 1995. The Translator's Visibility. A History of Translation. Londyn i Nowy Jork: Routledge.

Venuti, L. 1998. The Scandals of Translation. Towards an Ethics of Difference. Londyn i Nowy Jork: Routledge.

Wadensjö, C. 2001. Community interpreting, w: Baker M. (ed.) Routledge Encyclopedia of Translation Studies. Londyn i Nowy Jork: Routledge. 